\title{
Technological feasibility of preparing spaghetti enriched with some by-products of food industry in Egypt
}

\author{
Hassan $^{1}$, A .A; El- gharabli², M.M.; El-Desouky², A.I.; Eltanahy ${ }^{2}$ H.H.; Abd el slam¹ ${ }^{1}$ A.M. \\ ${ }^{1}$ Bakery \&Dough Dept., Food Technology Research Institute, Agricultural Research Center, Giza, Egypt. \\ ${ }^{2}$ Food Tech. Dept., Moshtohor Faculty of Agric. Banha Univ., Egypt.
}

\begin{abstract}
In this study, feasibility of using dry orange albedo, guava seed powder and tomato peel powder as a bywastes from food industry, as a starting raw material to produce dietary fiber powders of producing spaghetti were replaced with wheat flour $72 \%$ extraction (WF72\% ext.) At 5, 10, 15 and 20\%,5, 10, and 20, 10, 20, 30 and $20 \%$ respectively the chemical analysis as (crude proteins, ash, crude fibers, fat and moisture)and mineral analysis \{potassium $(\mathrm{K})$, calcium $(\mathrm{Ca})$, sodium $(\mathrm{Na})$, phosphor $(\mathrm{P})$, iron $(\mathrm{Fe})$ and $\mathrm{Zink}(\mathrm{Zn})\}$. were done for raw materials and all samples spaghetti showed the best in sensory evaluation(15\% dry orange albedo, $10 \%$ guava seed powder and $30 \%$ tomato peel powder. The pest rheological tests. Cooking quality properties (FirmnessWeight gain \% - Volume gain \% - Cooking loss \%) were done.
\end{abstract}

Keywords: Wheat flour $72 \%$-dietary fibers - dry orange albedo, guava seed powder and tomato peel powdercooking quality- rheological properties.

\section{Introduction}

Dietary fiber appear to be at significantly lower risk for developing coronary heart disease, stroke, hypertension, diabetes, obesity and certain gastrointestinal diseases. Increasing fiber intake lowers blood pressure and serum cholesterol levels. Increased intake of soluble fiber improves glycaemia and insulin sensitivity in non-diabetic and diabetic individuals. Fiber replacementation in obese individuals significantly enhances weight loss. Increased fiber intake benefits a number of gastrointestinal disorders including the following: gastro esophageal reflux disease, duodenal ulcer, diverticulitis, constipation, and hemorrhoids. Prebiotic fibers appear to enhance immune function. Dietary fiber intake provides similar benefits for children as for adults. The recommended dietary fiber intakes for children and adults are $14 \mathrm{~g} / 1000$ kcal. More effective communication and consumer education is required to enhance fiber consumption from foods or supplements,Angelica Bianca et al., (2015)

El Adly and Asma(2009) found that wheat flour (72\% extraction) contained $11.40 \%$ crude protein, $0.54 \%$ ash, and $0.66 \%$.crude fibers.

Abd-El-Hady (2012) showed that of wheat flour $72 \%$ ext. contained moisture $11.32 \%$ protein $0.78 \%$ ash $10.32 \%$, fibers $0.65 \%$ fat 0.755 and $88.32 \%$ total carbohydrates.

Babiker et al., (2013) found that of wheat flour contained moisture $11.65 \%$ protein $12.05 \%$, fiber $1.65 \%$, ash $1.47 \%$, fat $1.81 \%$ and $88.02 \%$ total carbohydrates

Bedeir, (2004) using Brabender Farinograph and Extensograph instruments to determining the rheological properties of wheat flour $(72 \%$ extraction). He found that, Farinograph parameters were $56.9,1.0,1.5,3.0$ and 105 for water absorption (\%), arrival time (min.), dough development time (min.), dough stability time (min.) and degree of softening (B.U), respectively. Also, he found that, Extensograph parameters for $420,125,3.36$ and 48 for dough resistance to extension (B.U), dough extensibility $(\mathrm{mm})$, proportional number and energy $\left(\mathrm{cm}^{2}\right)$, respectively.

The albedo is chemical composition moisture and nitrogen free extract contents (15.00\% and $78.22 \%)$ respectively, the moisture and nitrogen level high while with the lowest protein, ash and lipid contents Flavonoids were mildly detected in all extracts except the hydroethanolic albedo extract Oikehet al., (2012)

Ferndez-Ginéset al., (2003) evaluated the proximate composition of Dry orang albedo and stated that its high fiber content albedo could be considered as a potential fiber source

Albedo is a white spongy and cellulosic tissue which is the principal component, albedo is rich dietary fibers that it's had a better quality than other sources of dietary fibers due to the presence of associated bioactive compounds and functional such (Flavonoids and V.C) addition antioxidant properties, which may exert higher heath promoting effects than the dietary fiber itself, Tao et al., (2009).

Norshazila et al.,(2010) found that, guava seed wastes have high antioxidant potential, because they are rich in compounds that can delay oxidation and also, Packer et al., (2010) concluded that guava seed extracts are effective in retarding lipid oxidation in processed chicken meat at concentration of $60 \mathrm{mg}$ total phenolic compounds $/ \mathrm{kg}$ of meat.

El-Safyet al., (2012) used guava seeds as anreplacemental source of fiber in cooks.

Abdeldaiem,et al., (2014)and Ayman (2015) reported comical composition of guava seeds for 
their moisture, crude protein, total lipid, crude fiber, ash and total carbohydrate 8.8, 7.49, 11.39, 63.45and $7.22 \%$ successively and also he noticed that guava seeds contain on natural antioxidants their effects on human health with a lower risk of cardiovascular disease and cancer.

Thuaytong et al., (2011) found guava seeds contain antioxidant activity was ascorbic acid, garlic acid, equivalents, catechincinnamyl alcohol, ethyl benzoate, $\beta$-caryophyllene, (E)-3-hexenyl acetate, $\alpha$ bisaboleneand bioactive compounds with beneficial physiological and metabolic properties.

Fontanariet al.,(2008) found the value of $67 / 100 \mathrm{~g}$ for total dietary fiber for guava seed it obtained on new products based on fibers.

Giovannucciet al., (2002)reported comical composition of tomato peel waste contains on a dry basis $95.9 \mathrm{~g}$ lipid, $175.6 \mathrm{~g}$ crude protein, $495.3 \mathrm{~g}$ crude fiber, $36.4 \mathrm{~g}$ ash, $405.4 \mathrm{~g}$ insoluble fiber and total carbohydrates590.7 g per kilo-gram of residue).

Alvarado et al. (2001) reported comical composition of tomato peel waste contains on a dry basis $95.9 \mathrm{~g}$ lipid, $175.6 \mathrm{~g}$ crude protein, $495.3 \mathrm{~g}$ crude fiber, $36.4 \mathrm{~g}$ ash, $405.4 \mathrm{~g}$ insoluble fiber and $590.7 \mathrm{~g}$ total carbohydrates per kilo-gram of residue. It has been pro-posed that the use of tomato waste as feed for poultry may be a way of reducing the cost of feeding poultry and help to alleviate the problem of solid waste

Kauret al., (2008) reported that the peel part of tomato peel waste contains up to five times more than the pulp (on wet basis)where attracted considerable attention for its possible role in disease prevention but its high moisture levels and susceptibility to microbial spoilage make the storage and processing of this material quite problematic.

Accordingly, the purpose of this work was carried out to evaluate some properties of fiber obtained from dry orange albedo,guava seed powder and tomato peel powder by-products, in order to use them as a dietary fibers source in the enrichment of spaghetti. The obtained spaghetti were evaluated chemical composition, physically and organoliptically.

\section{Materials and Methods}

\subsection{Materials:}

Wheat flour of $72 \%$ ext. was obtained from South Cairo Flours Mills Company, Cairo, Egypt.

dry orange albedo, guava seed powder and tomato peel powder:

Were obtained from Kaha Company (Kaha, Kaluobia, Egypt).

\section{Preparation of spaghetti:}

Spaghetti samples were prepared from wheat flour $72 \%$ ext., water $35 \%$ and salt $1 \%$. Each sample was blended with different substitution level dray orange albedo (5, 10,15and 20\%), guava seed powder $(5,10$ and $15 \%)$, tomato peelpowder $(10,20$, 30 and 40) as wheat flour weight. The mixture of ingredients was placed in a mixing bowl (Kitchen Aid Mixer) and mixed at speed 1 for 2 min., water was added and mixing was continued at speed 1 for 4 min., followed by mixing at speed 2 until the dough stiffened. The dough was rounded (shape to ball). Covered with plastic wrap, allowed to rest about 30 min., hand kneaded for about $1 \mathrm{~min}$ and sheeted with wooden rolling pin to about $1.5 \mathrm{~cm}$. thickness. The sheet of dough was passed through a- pasta machine (Ampia, TipoLusso, Model 150 and Italy). Spaghetti was cut into strips $5 \mathrm{~mm}$ wide, the spaghetti was dried to $6.50 \%$ moisture in oven at $65 \mathrm{C}^{\circ}$ for one day, cooled at room temperature and the produced spaghetti was packed in polyethylene bag until tested cooking qualities of spaghetti under investigation namely optimum cooking time, spaghetti cooking weight and cooking loss were released by the method of (Dexter et al.,1983).

\subsection{Methods:}

3. 2.1. Moisture, fat, ash, crude fiber, crude protein and essential minerals were determined according to (A.O.A.C.2005). A total carbohydrate was calculated by difference. Total calories, calculated according to Kerolles (1986).

$\mathbf{E}=$ Energy as calories per $100 \mathrm{gms}$.

3.2.2. Determination of rheological properties:

Rheological properties of the dough's were determined using Farinograph and Extensograph according to A.A.C.C. (2005).

3.2.3.Dtermination of cooking quality of spahetti:

The methods describeedby Park et al. (2004) and Baiket al. (2003) were used to evaluate the cooking quality of instant pasta samples. Twenty five grams of noodles samples were transferred into pasta laboratory cooker containing $250 \mathrm{ml}$. of hot water $95 \mathrm{C}^{\mathrm{o}}$. After cooking for 10,15 and $20 \mathrm{~min}$, the samples were washed by cooling water thoroughly with distilled water and allowed to drain for $2 \mathrm{~min}$. Three measurements were conducted on the cooked pasta as follows:

\subsubsection{Weight increase (\%):}

This value was calculated as follows:

\section{Weight increase $=$}

Weight of cooked sample - weight of uncooked sample weight of uncooked sample

Volume increase \%(Swelling\%):

This value was calculated as follows:

Volume increase $=$

Volume of cooked sample - Volume of uncooked volume of uncooked sample weight of uncooked sample

3.2.6. Cooking loss $\%$ (Total soluble solids, T.S.S): 
Residue was determined by weighing the solid materials in cooking water after drying in an oven at $130 \mathrm{C}^{\circ}$ over night to a constant weight. Results were recorded as follows:

Cooking loss $\%=$

Weight of residues in cooking water Weight of uncooked sample

\subsection{Sensory evaluation:-}

For Sensory evaluation ten trained panelists from food Technology Research Institute members was use to examine and score of different parameters of organoleptic properties of the final products including Appearance (20) color (20), Tenderness (25) flavor (20), Stickiness (15) Overall acceptability (100) according to A.O.A.C. (2005)

\subsection{Statistical analysis:-}

Using of the statistical analysis system "SAS" (SAS Institute Inc., 1999).

\section{Result and Discussion}

4.1. Chemical composition of raw materials used in the preparation of spaghetti

Wheat flour:

Table (1): show comical composition of WF72\%ext. for their moisture, crude protein, total lipid, crude fiber, ash and total carbohydrate 11.8, $12.59,1.54,0.8,0.58$ and $84.49 \%$ respectively.

The protein and total carbohydrate the higher value $(12.59,84.49 \%)$ while ash and total lipid the lower value $(0.58,0.8 \%)$ the moisture content of WF $72 \%$ ext. was $11.8 \%$. This result is in similar with that Bilgicli et al. (2006) and Bilgicli and Ibanoglu (2007) who's reported that the WF72\% ext. was contents of $10.62 \%$ protein, $12.30 \%$ moisture, $0.61 \%$ ash, and $1.00 \%$ fat

\section{Dry orange albedo}

In Table (1) show comical composition of orange albedo for their moisture, crude protein, total lipid, crude fiber, ash and total carbohydrate 9.8, 4.4, 058, $17.01,3.4$ and $64.81 \%$ successively.

There results in agreement with Fernandez-Gines $\boldsymbol{e t}$ al.,(2004) where found albedo high content fiber were (17.91) and ash was (2.99), fat was (0.90) and total carbohydrates was $55.24 \%$ respectively. And nearly the results were agreement Manal and Hend (2014) proved that of dry orange albedo contained protein $4.24 \%$, fiber $9.13 \%$ ash $2.20 \%$ fat $6.41 \%$, moisture 13.19 and total carbohydrates $64.83 \%$.

Osfor et al.,(2013)who indicated the comical composition of orange albedo for their moisture, crude protein, total lipid, crude fiber, and ash $19.9,7.26,0.2,9.92$, and 2.3 consecutively he observed comical composition of orange albedo was rich in dietary fibers 9.92 dry weight basis

Guava seed powder

Values of Table (1) denoted comical composition of guava seeds for their moisture, crude protein, total lipid, crude fiber, ash and total carbohydrate 7.42 , 7.74, 15.88, 63.37 and $4.65 \%$ consecutively.EISafyet al., (2012) and Marquina et al., (2008) used guava seeds as an additional source of fiber in cookies,guava seeds had the highest amount of crude fiber $(64.00 \%)$ soguava seeds could be considered as a good source of dietary fiber

Fontanari et al., (2008) obtained the protein value of $8.2 \%$ when studying protein from guava seed.

\section{Tomato peel powder}

As shown in Table (1) chemical composition of tomato peel powder contain (on dry weight basis) 9.92\% crude protein, $4.24 \%$ ash, $2.55 \%$ the fat, $52.67 \%$ crude fiber and $20.59 \%$ total carbohydrate respectively. Knoblich et al. (2005) stated that comical composition contained tomato peels powder $10.08 \%$ protein, $5.64 \%$ ash and fibers $40.94 \%$ Arafa and Salaw (2009) found that tomato peel contained $11.6 \%$ fat $60.4 \%$ crude fiber, $1.20 \%$, total carbohydrate and $8.00 \%$ protein

Table 1. Chemical composition of raw materials used in the experimental spaghetti. ("on dry weight basis)

\begin{tabular}{lllllll}
\hline Raw material & Moisture & $\begin{array}{l}\text { Crude } \\
\text { proteins }\end{array}$ & $\begin{array}{l}\text { Crude } \\
\text { fibers }\end{array}$ & Ash & Fat & $\begin{array}{l}\text { Total } \\
\text { carbohydrates }\end{array}$ \\
\hline wheat flour72\% ext. & $11.8 \pm 0.9^{\mathrm{a}}$ & $12.59 \pm 0.34^{\mathrm{d}}$ & $0.8 \pm 0.1^{\mathrm{d}}$ & $0.58 \pm 0.06^{\mathrm{c}}$ & $1.54 \pm 0.2^{\mathrm{a}}$ & $84.49 \pm 1.56^{\mathrm{a}}$ \\
\hline Dry orange albedo & $9.8 \pm 0.45^{\mathrm{b}}$ & $4.4 \pm 0.5^{\mathrm{d}}$ & $17.01 \pm 0.99^{\mathrm{c}}$ & $3.40 \pm 0.4^{\mathrm{b}}$ & $0.58 \pm 0.02^{\mathrm{a}}$ & $64.81 \pm 2.01^{\mathrm{b}}$ \\
\hline Guava seeds Powder & $7.72 \pm 0.48^{\mathrm{c}}$ & $7.74 \pm 0.16^{\mathrm{c}}$ & $63.37 \pm 3.3^{\mathrm{a}}$ & $0.94 \pm 0.05^{\mathrm{c}}$ & $15.88 \pm 1.8^{\mathrm{a}}$ & $4.65 \pm 0.26^{\mathrm{c}}$ \\
\hline Tomato peel powder & $10 . .02 \pm 0 .^{\mathrm{b}}$ & $9.92 \pm 0.67^{\mathrm{a}}$ & $52.63 \pm 1^{\mathrm{a}}$ & $4.24 \pm 0.5^{\mathrm{a}}$ & $2.55 \pm 0^{\mathrm{a}}$ & $20.59 \pm 1.21^{\mathrm{b}}$ \\
\hline LSD & 19.884 & 25.028 & 39.161 & 64.806 & 0.938 & 0.289 \\
\hline * Mean of triplicate determination \pm standard deviation. . & & & & \\
** Calculated by difference. \\
*** Values with different superscripts in every column are significantly different (P>0.05). \\
****SD =least significant difference. \\
WF= wheat flour, (A) DO.A= dry orange albedo, (B) G.SP guava seed power and(C) TPP Tomato peel power
\end{tabular}




\subsection{Minerals content of raw materials:}

Table (2) shown the predominant first major mineral element in WF $72 \%$ ext.wasessential elements in wheat flour were arranged as follows $\mathrm{K}$ $(116.1 \mathrm{mg} / 100 \mathrm{~g}), \quad \mathrm{Ca} \quad(19.8 \mathrm{mg} / 100 \mathrm{~g}), \quad \mathrm{Na}$ $(4.01 \mathrm{mg} / 100 \mathrm{~g}), \mathrm{Fe}(1.22 \mathrm{mg} / 100 \mathrm{~g})$ and $\mathrm{Zn}(0.80$ $\mathrm{mg} / 100 \mathrm{~g})$.

WF72\%ext. had the lowest content and the no richest source for $\mathrm{K}(344.00,323.40$ and $317.00 \mathrm{mg} /$ $100 \mathrm{~g}$ ) by guava seeds, tomato peels and dry orang albedo respectively. Arshad et al. (2007) found that WF72\%ext.contain K $125 \mathrm{mg} / 100 \mathrm{~g}$, Ca 12.94 $\mathrm{mg} / 100 \mathrm{gand} \mathrm{Fe} 0.3 \mathrm{mg} / 100 \mathrm{~g}, \mathrm{mg} / 100 \mathrm{~g}$

In dry orang albedo, the predominant first major mineral element was also calcium (594 $\mathrm{mg} / 100 \mathrm{~g}$ ).Essential elements in dry orang albedo, arranged in a decreasing order of abundance, were as follows: $\mathrm{Zn}(1.48 \mathrm{mg} / 100 \mathrm{~g}), \mathrm{Fe}(9.90 \mathrm{mg} / 100 \mathrm{~g}), \mathrm{Na}$ $(39.60 \mathrm{mg} / 100 \mathrm{~g})$ and $\mathrm{K}(317 \mathrm{mg} / 100 \mathrm{~g})$. This result is in agreement with Doweidar, (2001). Reported that the albedo content of $\mathrm{Ca}(28.4 \mathrm{mg} / 100 \mathrm{~g})$ and $\mathrm{Na}$ $(51.7 \mathrm{mg} / 100 \mathrm{~g})$ in the rind is higher than that of the fruit pulp. It also presents a significant content of iron $(1.5 \mathrm{mg} / 100 \mathrm{~g})$ enabling its utilization as mineral source.

In the predominant first major mineral element was also Ca (392.00mg/100g), K (344.00 mg/100g), $\mathrm{Na}(315.56 \mathrm{mg} / 100 \mathrm{~g}), \mathrm{P}(210.70 \mathrm{mg} / 100 \mathrm{~g}) \mathrm{Fe}(31.05$ $\mathrm{mg} / 100 \mathrm{~g})$ and $\mathrm{Zn}(9.90 \mathrm{mg} / 100 \mathrm{~g}$. Essential elements in guava seed powder, arranged in an increasing

El-kassas(2004) found that the minerals content of guava seed powder were (mg/100g sample )Ca425.8, Fe 31.5 1, and $\mathrm{Zn} \mathrm{10.79,} \mathrm{respectively.}$

Essential elements in tomato peel powder arranged, in increasing order of abundance, were as follows: P (362.00 mg/100g), K (323.4 mg/100g), Na (322.00 mg/100g), Ca (142.10 mg/100g), Zn (10.80 $\mathrm{mg} / 100 \mathrm{~g})$ and $\mathrm{Fe}(4.50 \mathrm{mg} / 100 \mathrm{~g})$.Arafa and Salaw (2009) found that the $\mathrm{P}, \mathrm{K}, \mathrm{Na}$ and $\mathrm{Ca}$ are the major element in tomato peel powder. Where their values were $540,630,822$ and $345 \mathrm{mg} / 100 \mathrm{~g}$ respectively but the $\mathrm{Fe}$, and $\mathrm{Zn}$ are the mojer elements respectively.

Table 2. Minerals content of raw materials which with used in prepare spaghetti.

\begin{tabular}{|c|c|c|c|c|c|c|}
\hline \multirow[b]{2}{*}{ Raw material } & \multicolumn{4}{|c|}{ Macro elements } & \multicolumn{2}{|c|}{ Micro elements } \\
\hline & $\mathrm{K}$ & $\mathrm{Ca}$ & $\mathrm{Na}$ & $\mathrm{P}$ & $\mathrm{Fe}$ & $\mathrm{Zn}$ \\
\hline Wheatflour $72 \%$ ext. & $116.1 \pm 4.2^{\mathrm{C}}$ & $19.8 \pm 1.38^{\mathrm{d}}$ & $4.06 \pm 1.3^{\mathrm{b}}$ & $44.14 \pm 1.38^{\mathrm{c}}$ & $1.22 \pm 0.05^{\mathrm{d}}$ & $0.80 \pm 0.04^{\mathrm{d}}$ \\
\hline Dry Orange albedo & $317 \pm 11.37^{\mathrm{b}}$ & $594 \pm 12.87^{\mathrm{a}}$ & $39.6 \pm 1.43^{\mathrm{b}}$ & $69.30 \pm 2.5^{\mathrm{c}}$ & $9.90 \pm 0.26^{\mathrm{b}}$ & $1.48 \pm 0.05^{\mathrm{c}}$ \\
\hline Guava seeds powder & $344 \pm 12.4^{\mathrm{a}}$ & $392 \pm 14.06^{b}$ & $315.56 \pm 2.34^{\mathrm{a}}$ & $210.70 \pm 1.8^{\mathrm{b}}$ & $31.05 \pm 0.95^{\mathrm{a}}$ & $9.9 \pm 0.26^{\mathrm{b}}$ \\
\hline Tomato peel powder & $323.4 \pm 12.6^{\mathrm{b}}$ & $142.10 \pm 2.3^{\mathrm{b}}$ & $322 \pm 7.1^{\mathrm{a}}$ & $362 \pm 22.4^{\mathrm{b}}$ & $4.50 \pm 0.19^{c}$ & $10.8 \pm 018^{\mathrm{a}}$ \\
\hline LSD & 19.884 & 25.028 & 39.161 & 64.806 & 0.938 & 0.289 \\
\hline
\end{tabular}

\section{Sensory evaluation of spaghetti replacement with various wastes:}

Spaghetti replacement with dry orange albedo:

The samples of spaghetti were evaluated organoleptic by ten panelists for their appearance, color, flavor, tenderness and stickiness where scoured and their mean values were statistically analyzed using analysis of variance and least significant difference (LSD), as presented in Tables (3).

The data presented in Tables (3.4and 5) showed that there were no significant differences in appearance between control sample and those blends which containing 5, 10, 15 and $20 \%$ dry orange albedo

The data presented in Table (3) showed that there were no significant differences between control sample and these blends which containing $15 \%$ dry orange albedo. After that there were significant differences in color among spaghetti sample with 5, 10,15 and $20 \%$ of dry orange albedo and control sample.

The change in color may be due to the phenolic compounds and fibers, with present in dry orange albedo, data indicated that there were significant differences in flavor among spaghetti control sample and those blends which containing 5, 10, 15 and 20\% dry orange albedo, also no significant differences stickiness among spaghetti control sample and those blends which containing 5, 10, 15 and 20\% dry orange albedo.Finally the overall acceptability score were increased by adding dry orange albedo (expect at $20 \%$ ).

In agreement to the obtained results were confirmed by those obtained by Abd el slam etal.,(2005).

\section{Spaghetti replacement with guava seeds powder:}

The data presented in Table (3) showed that there were no significant differences in appearance and stickiness between control sample and these blends among spaghetti control sample and those blends which containing 5, 10 and $15 \%$ guava seeds flour and no significant differences between control sample and these blends which containing $10 \%$ guava seeds flour. After that there were significant differences in color among spaghetti sample with 5, 10 and $15 \%$ of guava seeds flour and control sample. 
The change in color may be due to fibers. On the other hand were significant differences in flavor among spaghetti control sample and those blends which containing 5, 10 and $15 \%$ guava seeds flour and the overall acceptability score were increased by adding guava seeds flour (expect at 15\%).In agreement to the obtained results were confirmed by those obtained by Haiat (2012) and Ahmed et al., (2011).

Spaghetti replacement with tomato peels powder:

The data presented in Table(3) showed that there were no significant differences in appearance, stickiness and color between control sample and these blends among spaghetti control sample and those blends which containing 10, 20, 30 and $40 \%$ spaghetti supplemented with tomato peel powder. The change in color may be due to the phenolic compounds, and were significant differences in flavor among spaghetti control sample and those blends which containing 10, 20, 30 and $40 \%$ spaghetti replaemented with tomato peel powder. Finally the overall acceptability score were increased by adding tomato peel powder (expect at 40\%). In agreement to the obtained results were confirmed by those obtained by Marwa (2013). We choose three samples which were had highest numbers in sensory attribute value as to meak the rheological properties for this sample.

Table 3. Effect of replacing extraction with some product wastes (A, B, C) on sensory evaluation test on spaghetti cooking properties

(A)

\begin{tabular}{|c|c|c|c|c|c|c|c|}
\hline Treatment & \multicolumn{2}{|c|}{$\begin{array}{l}\text { Appearance } \\
(20)\end{array}$} & $\begin{array}{l}\text { Color } \\
(20)\end{array}$ & Tenderne(25) & Flavor(20) & Stickiness(15) & $\begin{array}{l}\text { Overall } \\
\text { accptability (100) }\end{array}$ \\
\hline $\begin{array}{l}\text { Control } \\
\text { wheat } 72 \%\end{array}$ & \multicolumn{2}{|c|}{$17.9^{\mathrm{ab}} \pm 0.1$} & $7 .^{\mathrm{ab}} \pm 1.0$ & $22.7^{\mathrm{ab}} \pm 0.7$ & $17.8^{\mathrm{ab}} \pm 0.2$ & $13^{\mathrm{ab}} \pm 0.5$ & $94.2^{\mathrm{b}} \pm 0.2$ \\
\hline $\begin{array}{l}\text { Dry orange } \\
\text { albedo } 5 \%\end{array}$ & \multicolumn{2}{|c|}{$17.8^{\mathrm{ab}} \pm 0.2$} & $7.5^{\mathrm{b}} \pm 0.5$ & $21.9^{\mathrm{b}} \pm 1.1$ & $17.4^{\mathrm{b}} \pm 0.4$ & $12.8^{\mathrm{b}} \pm 0.2$ & $93.9^{\mathrm{b}} \pm 1.1$ \\
\hline $\begin{array}{l}\text { Dry orange } \\
\text { albedo } 10 \%\end{array}$ & \multicolumn{2}{|c|}{$17.2^{\mathrm{b}} \pm 0.2$} & $7.7^{c} \pm 0.3$ & $21.8^{\mathrm{b}} \pm 0.2$ & $17.5^{\mathrm{b}} \pm 0.5$ & $12.9^{\mathrm{b}} \pm 1.1$ & $94.6^{\mathrm{b}} \pm 0.6$ \\
\hline $\begin{array}{l}\text { Dry orange } \\
\text { albedo } 15 \%\end{array}$ & \multicolumn{2}{|c|}{$18.6^{\mathrm{a}} \pm 0.6$} & $8.7^{\mathrm{a}} \pm 0.6$ & $23.1^{\mathrm{a}} \pm 0.9 \pm 0.9$ & $18.7^{\mathrm{a}} \pm 0.7$ & $13.8^{\mathrm{a}} \pm 0.2$ & $97.0^{\mathrm{a}} \pm 2.0$ \\
\hline $\begin{array}{l}\text { Dry orange } \\
\text { albedo } 20 \%\end{array}$ & \multicolumn{2}{|c|}{$13.5^{\mathrm{c}} \pm 1.5$} & $3.3^{c} \pm 0.7$ & $20.6^{c} \pm 0.4$ & $13.7^{\mathrm{c}} \pm 0.3$ & $11.1^{\mathrm{c}} \pm 0.9$ & $93.3^{\mathrm{c}} \pm 1.3$ \\
\hline LSD & \multicolumn{2}{|c|}{1.014} & .934 & 1.039 & 1.012 & 0.817 & 1.334 \\
\hline \multicolumn{8}{|l|}{ (B) } \\
\hline Treatment & \multicolumn{2}{|c|}{$\begin{array}{l}\text { Appearance } \\
(20)\end{array}$} & $\begin{array}{l}\text { Color } \\
(20)\end{array}$ & Tenderne(25) & Flavor(20) & Stickiness(15) & $\begin{array}{l}\text { Overall } \\
\text { accptability } \\
(100)\end{array}$ \\
\hline Control wheat & & & & & & & \\
\hline $72 \%$ & & ${ }^{a b} \pm 0.1$ & $17.5^{b} \pm 0.5$ & $22.7^{\mathrm{ab}} \pm 0.7$ & $17.4^{\mathrm{b}} \pm 0.6$ & $13^{\mathrm{ab}} \pm 0.5$ & $94.2^{\mathrm{b}} \pm 0.2$ \\
\hline $\begin{array}{l}\text { Guava } \\
\text { seeds5\% }\end{array}$ & & $\mathrm{a} \pm 0.2$ & $18.7^{\mathrm{a}} \pm 0.4$ & $21.9^{\mathrm{b}} \pm 0.6$ & $18.4^{\mathrm{a}} \pm 0.4$ & $12.8^{\mathrm{b}} \pm 0.2$ & $93.9^{b} \pm 1.1$ \\
\hline Guava seeds & & & & & & & \\
\hline $10 \%$ & 15 & & $17.7^{\mathrm{b}} \pm 0.7$ & $23.1^{\mathrm{a}} \pm 0.3$ & $17.5^{\mathrm{b}} \pm 0.5$ & $13.8^{\mathrm{a}} \pm 0.8$ & $97^{\mathrm{a}} \pm 1.0$ \\
\hline $\begin{array}{l}\text { Guava } \\
\text { seeds } 15 \%\end{array}$ & & $\mathrm{a} \pm 0.8$ & $17.5^{\mathrm{b}} \pm 0.5$ & $21.8^{\mathrm{b}} \pm 0.8$ & $17.4^{\mathrm{b}} \pm 0.6$ & $12.8^{\mathrm{b}} \pm 0.8$ & $94.0^{\mathrm{b}} \pm 3.0$ \\
\hline LSD & & & 0.936 & 1.0412 & 1.009 & 0.802 & 1.176 \\
\hline (C) & & & & & & & \\
\hline Treatment & & $\begin{array}{l}\text { Appearance } \\
(20)\end{array}$ & $\begin{array}{l}\text { Color } \\
(20)\end{array}$ & Tenderne(25) & Flavor(20) & Stickiness(15) & $\begin{array}{l}\text { Overall } \\
\text { acceptability } \\
(100)\end{array}$ \\
\hline Control wheat 7 & $72 \%$ & $17.9^{\mathrm{ab}} \pm 0.1$ & $17 .^{\mathrm{ab}} \pm 1.0$ & $22.7^{\mathrm{ab}} \pm 0.7$ & $17.8^{\mathrm{ab}} \pm 0.2$ & $13^{\mathrm{ab}} \pm 0.5$ & $94.2^{\mathrm{b}} \pm 0.2$ \\
\hline Tomato peels 10 & & $17.8^{\mathrm{ab}} \pm 0.8$ & $17.5^{\mathrm{b}} \pm 0.5$ & $21.9^{\mathrm{b}} \pm 0.1$ & $17.4^{\mathrm{b}} \pm 0.4$ & $12.8^{\mathrm{b}} \pm 1.2$ & $93.9^{\mathrm{b}} \pm 0.1$ \\
\hline Tomato peels 2 & & $17.2^{\mathrm{b}} \pm 0.8$ & $17.7^{\mathrm{b}} \pm 0.7$ & $21.9^{\mathrm{b}} \pm 1.1$ & $16.9^{b} \pm 0.1$ & $12.5^{\mathrm{b}} \pm 0.5^{2}$ & $94.2^{\mathrm{b}} \pm 0.8$ \\
\hline Tomato peels 3 & $0 \%$ & $18.6^{\mathrm{a}} \pm 0.6$ & $18.7^{\mathrm{a}} \pm 0.3$ & $23.1^{\mathrm{a}} \pm 1.1$ & $18.6^{\mathrm{a}} \pm 1.6$ & $13.8^{\mathrm{a}} \pm 0.2$ & $97.0^{\mathrm{a}} \pm 1.0$ \\
\hline Tomato peels 4 & $40 \%$ & $13.3^{\mathrm{c}} \pm 0.3$ & $13.3^{\mathrm{c}} \pm 1.3$ & $20.6^{c} \pm 0.4$ & $13.7^{\mathrm{b}} \pm 0.7$ & $11.1^{\mathrm{c}} \pm 0.9$ & $93.3^{\mathrm{b}} \pm 1.7$ \\
\hline LSD & & 1.028 & 0.935 & 1.004 & 1.808 & 0,817 & 1.344 \\
\hline
\end{tabular}


Rheological properties of baked dough: Brabender farinograph dough properties:

The results presented in Table (4) showed the effect of adding $15 \%$ of dry orange albedo, $10 \%$ guava seed powder and 30\% of tomato peel powder to wheat flour on Farinograph parameters i.e., water absorption (\%), dough development time (min.), dough stability time (min.), and degree of softening (B.U).

From the obtained data, it could be noticed that the water absorption increased from $58 \%$ for control sample to $66.0,70.0$ and $79.3 \%$ as a result to the addition of $15 \%$ of the albedo, $10 \%$ of guava seed powder and $30 \%$ tomato peel powder this finding could be attributed to the higher fiber content of the above mentioned waste. such data are in the same line with those of Abd El-Moniem and Yassen (1993) and Haiat (2012) reported that addition of guava seeds flour to wheat flour increased the water aborption in wheat flour $72 \%$ extraction. This increase due to high fiber contents.

It could be observed that the stability time of wheat flour control dough decreased from $16.5 \mathrm{~min}$. to 5.00 as a result to addition of $15 \%$ of the albedo, $10 \%$ of guava seed powder and $30 \%$ tomato peel powder to dough's. This observation might be due to the higher fiber content for the above mentioned waste. The decrement in the stability time would indicate weakness in dough strength. This weakness of dough might be attributed to the dilution of wheat gluten as a result to addition of the aforementioned waste.

Marrow (2013) and Sogi et al.,(2002) found that farinograph test of wheat flour replacement with tomato peel powder increase in water absorption, time increased dough development time and time decreased dough stability and also it could be observed that tomato peels are rich in crude fiber and ash comparing with wheat flour, therefore, addition of tomato peel powder replacement of wheat flour will be increase the protein, crude fiber and ash content in the final product.

\section{Brabender Extensograph dough properties:}

Data presented in Table (4) showed the effect of adding $15 \%$ of dry orange albedo, $10 \%$ guava seed powder and $30 \%$ of tomato peel powder to wheat flour on extensograph parameters i.e. extensibility $(\mathrm{mm})$, resistance to extension (B.U), proportional number and energy of dough $\left(\mathrm{cm}^{2}\right)$.

From the obtained data, it could be noticed that the extensibility of wheat flour dough decreased as a result of adding 10,15and 30 of the supplemented guava seeds, dry orange albedo and tomato peels to where they reached the 65,130 and $150 \mathrm{~mm}$, respectively, compared to $180 \mathrm{~mm}$. for wheat flour control dough.

On the other hand, data showed that resulted in decreasing the resistance to extension values from 780 B.U in control dough sample to 440,105 and 120 B.U, respectively. This finding may be due to the effect of adding these waste on wheat gluten. Results also showed that the values for proportional number were slightly increased as a result of adding of $15 \%$ of dry orange albedo, $10 \%$ guava seeds and 30\% of tomato peels to doughs of wheat flour (control sample). Concerning to the energy valued the control sample recorded the highest value $\left(120 \mathrm{~cm}^{2}\right)$, while doughs replacement with waste showed lower energy values indoughs. These findings are in general accordance to those reported by Haiat (2012) she found that the resistance to extension, proportional number and energy of dough were decreased.

Table 4. Barabender farinograph and extensograph properties of doughs used to prepare spaghetti from wheat flour. whenreplacing with different levels of with some processing wastes

\begin{tabular}{|c|c|c|c|c|}
\hline \multicolumn{5}{|l|}{ Farinograph parameter } \\
\hline Kind of supplementation to doughs & $\begin{array}{l}\text { Water absorption } \\
(\%)\end{array}$ & $\begin{array}{l}\text { Dough } \\
\text { development } \\
\text { (min.) }\end{array}$ & $\begin{array}{l}\text { Dough } \\
\text { stability } \\
\text { (min.) }\end{array}$ & $\begin{array}{l}\text { Dough } \\
\text { weakening } \\
\text { (B.U) }\end{array}$ \\
\hline $\begin{array}{l}\text { Control Sample } \\
\text { (without supplementation) }\end{array}$ & 58 & 2.5 & 16.5 & 15 \\
\hline $\mathrm{WF}+15 \% \mathrm{DOA}$ & 70 & 12 & 10 & 50 \\
\hline $\mathrm{WF}+10 \% \mathrm{GSP}$ & 66 & 12 & 8 & 30 \\
\hline $\mathrm{WF}+30 \% \mathrm{TPP}$ & 79.3 & 14 & 5 & 60 \\
\hline \multicolumn{5}{|l|}{ Extensograph parameter } \\
\hline Dough mixture & Res.to $\operatorname{Ext}(\text { B.U })^{2}$ & Extensibility & P.N & Energy \\
\hline Control group(WF) & 780 & 180 & 4.9 & 120 \\
\hline $\mathrm{WF}+15 \% \mathrm{DOA}$ & 105 & 130 & 10.4 & 40 \\
\hline $\mathrm{WF}+10 \%$ GSP & 440 & 65 & 8.2 & 30 \\
\hline $\mathrm{WF}+30 \% \quad \mathrm{TPP}$ & 120 & 150 & 6.7 & 56 \\
\hline
\end{tabular}

Dry orange albedo (DOA) Guava seed powder (GSP)- -Tomato peel powder (TPP).

Res.to Ext $(\mathrm{B} . \mathrm{U})^{2}=$ resistance to Extenstion

P.N = proportional Number 
Chemical constituents of spaghetti.

Spaghetti replacement with dry orange albedo:

In Table(5) show effect of replacing wheat flour $72 \%$ ext.by dry orange albedo was crude protein was decreased in orange albedo of spaghetti substitution at levels of 5, 10,15 and 20\% was 12.06,11.56,11.25 and $10.48 \%$ respectively compared of spaghetti control was $12.46 \%$. Ash and crude fibers content were increased $0.71,0.85,0.99$ and $1.13 \%$ and. 1.6, $2.41,3.22$ and $4.03 \%$ consecutively compared with control 0.57 and $0.79 \%$. Moisture and carbohydrates content was decreased in spaghetti from made of dry orange albedo substitution at all levels compared of spaghetti control. Regardless of level of substitution of WF $72 \%$ ext. by dry powdered orange albedo content of their resultant spaghetti to increase in fibers and ash but crude protein, crude fat and total carbohydrates decreased

These studied the effect of supplementing orange albedo on the chemical composition of Egyptian baked production and found that the dry powdered orange albedo layer contained high crude fibers. These results are well in line by those obtained by Doweidar et al., (2001) and Abd el slam etal.,(2005).who studied the effect of replacementing dry powered orange albedo on the chemical composition of Egyptian baked products who found that the dry powered orange albedo layer contained high crude fibers.

\section{Spaghetti replacement with guava Seed powder:}

In Table (5) show Effect of replacing wheat flour $72 \%$ ext. by guava Seeds. Crude protein content was decreased in guava seed powder of spaghetti substitution at levels of 5, 10 and $15 \%$ successively in guava seeds from $72 \%$ ext.12.21, 11.99 and $11.75 \%$ successively compared of spaghetti control with $72 \%$ ext. 12.46. but ash, crude fats and crude fiber content were increased in guava seeds of spaghetti substitution at different levels of $(0.58,0.60$ and $0.62 \%),(2.28,2.99$ and 3.70$)$ and $(3.92,7.03$ and $10.15 \%)$ respectively. compared of spaghetti control with $72 \%$ ext. $0.57,1.57$ and $0.79 \%$. Moisture and carbohydrates content were decreased in spaghetti made of substitution at different levels of guava seed powder consecutively in $(10.92,10.73$ and 10.54$)$ and (81.01, 77.39 and $73.74 \%$ ) consecutively compared of spaghetti control with $72 \%$ ext. 11.1 and $84.61 \%$ substitution, substituting of WF of $72 \%$ by guava seeds content of their resultant Regardless of level of spaghetti to increase in fibers, fat and ash but crude protein, and total carbohydrates decreased These results were agreement the Ahmed et al., (2011)

\section{Spaghetti replacement with tomato peels:}

In Table (5) show effect of replacing wheat flour $72 \%$ ext. by tomato peels. Crude protein was decrease $(12.20,11.95,11.70$ and $11.43 \%$,) compared with control $(12.46 \%)$. but ash, crude fibers and fat content were increased in tomato peel powder of spaghetti substitution at levels of 10,20,30and $40 \%$ consecutively in tomato peels from $72 \%$ ext.(0.93,1.34,1.67 and 2.04\%),(5.97,11.16,16.36and $21.53 \%)$ and $(1.66,1.77,1.86$ and $1.96 \%)$ consecutively compared of spaghetti control with $72 \%$ ext.( $0.57,0.79$ and $1.57 \%)$.on the other hand moisture and carbohydrates content were decreased. Regardless of level of substitution, substituting of WF of $72 \%$ by tomato peels content of their resultant spaghetti to increase in fibers and ash, fat but crude protein and total carbohydrates decreased. These studied the effect of supplementing tomato peel powder on the chemical composition of spaghetti and found that tomato peels contained high crude fiber these results was agreement the Sonja and Djilas (2010).

Table 5. Effect of replacing wheat flour with some some processing wastes (A, B, C)

\begin{tabular}{lllllll}
\hline Raw material & Moisture & $\begin{array}{l}\text { Crude } \\
\text { proteins }\end{array}$ & $\begin{array}{l}\text { Crude } \\
\text { fibers }\end{array}$ & Ash & Fat & $\begin{array}{l}\text { Total } \\
\text { carbohydrates }\end{array}$ \\
\hline $\begin{array}{l}\text { control (WF 72\% } \\
\text { ext.) }\end{array}$ & $12.46 \pm 0.34^{\mathrm{a}}$ & $0.57 \pm 0.03^{\mathrm{d}}$ & $0.79 \pm 0.02^{\mathrm{e}}$ & $1.57 \pm 0.02^{\mathrm{a}}$ & $84.61 \pm 0.71^{\mathrm{a}}$ & $11.1 \pm 0.4^{\mathrm{a}}$ \\
95\%WF+ 5\%DOA & $12.06 \pm 0.03^{\mathrm{a}}$ & $0.71 \pm 0.04^{\mathrm{d}}$ & $1.6 \pm 0.3^{\mathrm{d}}$ & $1.52 \pm 0.23^{\mathrm{a}}$ & $84.11 \pm 1.61^{\mathrm{a}}$ & $11.08 \pm 0.17^{\mathrm{a}}$ \\
90\%WF+ & & & & & & \\
10\%DO.A & $11.56 \pm 0.94^{\mathrm{c}}$ & $0.85 \pm 0.07^{\mathrm{b}}$ & $2.41 \pm 0.19^{\mathrm{c}}$ & $1.47 \pm 0.08^{\mathrm{a}}$ & $83.71 \pm 0.81^{\mathrm{a}}$ & $10.97 \pm 0.11^{\mathrm{a}}$ \\
$85 \% \mathrm{WF}+$ & & & & & & \\
$15 \% \mathrm{DOA}$ & $11.25 \pm 0.7^{\mathrm{c}}$ & $0.99 \pm 0.03^{\mathrm{b}}$ & $3.22 \pm 0.19^{\mathrm{b}}$ & $1.42 \pm 0.4^{\mathrm{a}}$ & $84.25 \pm 1.51^{\mathrm{a}}$ & $10.9 \pm 0.4^{\mathrm{a}}$ \\
$80 \% \mathrm{WF}+20 \%$ DOA & $10.48 \pm 0.62^{\mathrm{c}}$ & $1.13 \pm 0.17^{\mathrm{a}}$ & $4.03 \pm 0.06^{\mathrm{a}}$ & $1.38 \pm 0.02^{\mathrm{a}}$ & $82.62 \pm 0.24^{\mathrm{a}}$ & $10.86 \pm 0.6^{\mathrm{a}}$ \\
LSD & 0.9776 & 0.157 & 0.3317 & 0.3817 & 1.8432 & 0.6966 \\
\hline
\end{tabular}

(B)

\begin{tabular}{lllllll}
\hline Raw material & Moisture & $\begin{array}{l}\text { Crude } \\
\text { proteins }\end{array}$ & $\begin{array}{l}\text { Crude } \\
\text { fibers }\end{array}$ & Ash & Fat & $\begin{array}{l}\text { Total } \\
\text { carbohydrates }\end{array}$ \\
\hline $\begin{array}{l}\text { control }(\mathrm{WF} \\
72 \% \text { ext.) }\end{array}$ & $12.46 \pm 0.34^{\mathrm{a}}$ & $0.57 \pm 0.03^{\mathrm{d}}$ & $0.79 \pm 0.02^{\mathrm{e}}$ & $1.57 \pm 0.02^{\mathrm{a}}$ & $84.61 \pm 0.71^{\mathrm{a}}$ & $11.1 \pm 0.4^{\mathrm{a}}$ \\
\hline $\begin{array}{l}95 \% \mathrm{WF}+ \\
5 \% \mathrm{GS} \mathrm{P}\end{array}$ & $12.21 \pm 0.16^{\mathrm{a}}$ & $0.58 \pm 0.01^{\mathrm{a}}$ & $3.92 \pm 0.08^{\mathrm{c}}$ & $2.28 \pm 0.12^{\mathrm{c}}$ & $81.01 \pm 0.51^{\mathrm{b}}$ & $10.92 \pm 0.13^{\mathrm{a}}$ \\
\hline
\end{tabular}




\begin{tabular}{lllllll}
\hline $90 \% \mathrm{WF}+$ & & & & & & \\
$10 \%$ GS P & $11.99 \pm 0.26^{\mathrm{ab}}$ & $0.6 \pm 0.05^{\mathrm{a}}$ & $7.03 \pm 0.47^{\mathrm{b}}$ & $2.99 \pm 0.06^{\mathrm{b}}$ & $77.39 \pm 0.8^{\mathrm{c}}$ & $10.73 \pm 0.48^{\mathrm{a}}$ \\
\hline $85 \% \% \mathrm{WF}+$ & & & & & & \\
$15 \%$ GS P & $11.75 \pm 0.3^{\mathrm{b}}$ & $0.62 \pm 0.05^{\mathrm{a}}$ & $10.15 \pm 0.35^{\mathrm{a}}$ & $3.7 \pm 0.3^{\mathrm{a}}$ & $73.78 \pm 1.28^{\mathrm{d}}$ & $10.54 \pm 0.19^{\mathrm{a}}$ \\
\hline LSD & 0.5146 & 0.0731 & 0.5571 & 0.31 & 0.6269 & 1.6465 \\
\hline
\end{tabular}

(C)

\begin{tabular}{lllllll}
\hline Raw material & Moisture & $\begin{array}{l}\text { Crude } \\
\text { proteins }\end{array}$ & $\begin{array}{l}\text { Crude } \\
\text { fibers }\end{array}$ & Ash & Fat & $\begin{array}{l}\text { Total } \\
\text { carbohydrates }\end{array}$ \\
\hline Control (WF 72\% ext.) & $12.46 \pm 0.34^{\mathrm{a}}$ & $0.57 \pm 0.03^{\mathrm{d}}$ & $0.79 \pm 0.02^{\mathrm{e}}$ & $1.57 \pm 0.02^{\mathrm{a}}$ & $84.61 \pm 0.71^{\mathrm{a}}$ & $11.1 \pm 0.4^{\mathrm{a}}$ \\
\hline $90 \%(\mathrm{WF}+10 \%$ TP P & $12.20 \pm 0.7^{\mathrm{a}}$ & $0.93 \pm 0.18^{\mathrm{a}}$ & $5.97 \pm 0.28^{\mathrm{d}}$ & $1.66 \pm 0.04^{\mathrm{c}}$ & $79.25 \pm 0.77^{\mathrm{b}}$ & $10.99 \pm 0.26^{\mathrm{a}}$ \\
\hline $80 \%(\mathrm{WF}+20 \%$ T P P & $11.95 \pm 0.3^{\mathrm{ab}}$ & $1.34 \pm 0.16^{\mathrm{a}}$ & $11.16 \pm 0.39^{\mathrm{c}}$ & $1.77 \pm 0.03^{\mathrm{ac}}$ & $73.78 \pm 0.32^{\mathrm{c}}$ & $10.88 \pm 0.11^{\mathrm{a}}$ \\
\hline $70 \%(\mathrm{WF}+30 \%$ TP P & $11.70 \pm 0.25^{\mathrm{ab}}$ & $1.67 \pm 0.12^{\mathrm{a}}$ & $16.36 \pm 0.54^{\mathrm{b}}$ & $1.86 \pm 0.14^{\mathrm{ab}}$ & $68.41 \pm 0.49^{\mathrm{d}}$ & $10.78 \pm 0.21^{\mathrm{a}}$ \\
\hline $60 \%(\mathrm{WF}+40 \%$ TP P & $11.43 \pm 0.62^{\mathrm{ab}}$ & $2.04 \pm 0.3^{\mathrm{a}}$ & $21.53 \pm 0.47^{\mathrm{a}}$ & $1.96 \pm 0.29^{\mathrm{a}}$ & $63.04 \pm 1.46^{\mathrm{e}}$ & $10.67 \pm 0.17^{\mathrm{a}}$ \\
\hline LSD & 0.866 & 0.8248 & 0.7015 & 0.2656 & 1.5375 & 0.455 \\
\hline
\end{tabular}

* Mean of triplicate determination \pm standard deviation.

** Calculated by difference.

$* * *$ Values with different superscripts in every column are significantly different $(\mathrm{P}>0.05)$.

$* * * *$ LSD $=$ least significant difference.

WF $72 \%$ ext. $=$ wheat flour $72 \%$ extraction,$(A)$ DO.A $=$ dry orange albedo, (B) GSPguava seed power and $(\mathrm{C}) \mathrm{TPP}$ Tomato peel power

Minerals content of spaghetti replacement with dry orange albedo, guava seed powder and tomato peel powder:

Spaghetti replacement with dry orange albedo:

In Table show (6) effect of replacing wheat flour $72 \%$ ext. by dry orange albedo substitution level $5,10,15$ and $20 \%$ respectively resulted in increasing of concentrations of macro element $\mathrm{K}, \mathrm{Ca}, \mathrm{Na}, \mathrm{P}$ and increasing of concentrations of micro element $\mathrm{Fe}, \mathrm{Zn}$.

(K, Ca, Na, P) constituted the major essential major element in dry orange albedo substituted at $5,10,15$ and $20 \%$, in spaghetti prepared form WF $72 \%$ ext. (125, 135,145.3 and 155.4), (45.82,77.4.105.76 and 134.48), (5.67,7.56,9.34 and $11.12)$ and (44.97, 46.26 , 47.53 and 48.82)Successively in spaghetti, compared of spaghetti control with $72 \%$ ext.(115.00, 19.60,4.01 and 43.70) of concentrations of macro element higher $\mathrm{K}, \mathrm{Ca}, \mathrm{Na}$ and Palso increased in concentrations of micro element $\mathrm{Fe}, \mathrm{Zn}$ to all samples.

These results are well in line. Abd el slam etal.,(2005). who noticed dry orange albedo at levels of 5,10 , and $15 \%$ replacing wheat flour $72 \%$ ext. to product paste that the observed increase in the minerals content of their corresponding prepared paste

Spaghetti replacement with guava seed powder:

Table (6): show effect of replacing WF $72 \%$ ext. by guava seed powder. The inclusion of guava seed powder prepared spaghetti, regardless of its substitution level 5, 10 and15\% respectively in from guava seedpowder $72 \%$ ext. resulted in increasing of concentrations of macro element $\mathrm{K}, \mathrm{Ca}, \mathrm{Na}$ and $\mathrm{P}$ increasing of concentrations of micro element $(\mathrm{Fe})$ constituted the major essential major element in guava seed powder substituted at 5,10 and $15 \%$ in spaghetti, prepared form WF $72 \%$ ext. on the other hand $(\mathrm{Zn})$ constituted lower concentrations

In agreement to the obtained results were confirmed by those obtained by Ahmed et al., (2011) noticed that the minerals such as calcium, potassium, iron, and zinc are considered as essential elements to human in guava seeds flour. The inclusion of guava seeds in spaghetti, regardless of its substitution level $1,2,3$ and $4 \%$ respectively in from guava seeds $72 \%$ ext.

\section{Spaghetti replacement with tomato peels:}

Table (6): show effect of replacing WF $72 \%$ ext. by tomato peels. The inclusion of tomato peel powder in spaghetti, regardless of its substitution level 10,20,30 and $40 \%$ respectively. Resulted in increasing of concentrations of macro and micro element $\mathrm{K}, \mathrm{Ca}, \mathrm{Na}$ and $\mathrm{P}$ and $\mathrm{Fe}, \mathrm{Zn}$ Compared with WF

$72 \%$ ext.K(135.8,156.6,176.9and198.2mg/100g), Ca(31.82 ,44.10,56.36and68.60mg/100g), $\mathrm{Na}(35.80,67.60,99.4$ 0and $131.202 \mathrm{mg} / 100 \mathrm{~g})$ and P $(75.53,107.36$, 139.19 and $171.022 \mathrm{mg} / 100 \mathrm{~g}$ ) respectively compared of spaghetti control with $72 \%$ ext. and micro element Fe $(1.53,1.86,2.19$ and $2.52 \mathrm{mg} / 100 \mathrm{~g})$ and $\mathrm{Zn}(1.79$, $2.79,3.79$ and $5.06 \mathrm{mg} / 100 \mathrm{~g})$ these results were agreement by Martinez et al,. (2002).

\section{Cooking quality properties:}

Spaghetti replacement with dry orang albedo:

In addition values for the cooking quality properties were increased by the increasing level of substitution where weight gain reached 190, 195, 210 and 281\% respectively. In the spaghetti with substitution dry orange albedo. Volume gain were also increased to 198, 204, 214 and 216\%., respectively. 
Similarly, cooking loos values were increased: 7.07, 7.4, 7.6and $10.1 \%$ compared with control $(182,190$ and $6.80 \%$ ) respectively The results for cooking quality are agreement with by those obtained by Abd el slam etal.,(2005). who reported that replacing of orange albedo layer at different levels increased volume, possibly because of its higher content in crude fibers.

The inclusion and substitution of wheat flour by orange albedo flour at levels of 5.10, 15and $20 \%$ increased firmness values by increasing level of substitution where it reached 2.13, 2.17, 2.25and $2.99 \mathrm{~kg} / \mathrm{cm}^{2}$ compared with control in spaghetti 1.45 $\mathrm{kg} / \mathrm{cm}^{2}$

Cooking loos was increased to 7.07, 7.4, 7.6and 10.1, respectively.

The results for cooking quality are agreement with by those obtained by Abd el slam et al.(2005)she reported that replacing of orange albedo layer at different levels increased volume, possibly because of its higher content in crude fibers.

Spaghetti replacement with guava seeds powder: Table(6) show effect of adding different ratios from milled guava seed on spaghetti cooking properties that show cooking quality(Cooking loos $\%$, volume gain $\%$, weight gain $\%$ and firmness $\%$ ) prepared from wheat flour $72 \%$ extraction substituted by different levels of some natural products $(5,10$,and $15 \%$ ),increased firmness values by increasing level of substitution where it reached 2.5, 2.7, and $3 \mathrm{~kg} / \mathrm{cm}^{2}$ in the $72 \%$ ext. Compared with control in spaghetti $1.45 \mathrm{~kg} / \mathrm{cm}^{2}$

In addition values for the cooking quality properties were increased by the inclusion and increasing level of substitution where weight gain reached 185 , 190 and $195 \%$ respectively In the $72 \%$ ext., volume gain were also increased to 195,198 and $200 \%$ in the $72 \%$ ext. Group, respectively. Similarly, cooking loos values were increased 6,7 and $9.5 \%$ in the $72 \%$ ext. group, respectively

It was clear from the recorded data that increasing the addition level of guava seeds flour to wheat flour $72 \%$ ext. Used for preparing Spaghetti increased the absorbed water, so the volume gain was also increased of cooked spaghetti. In spite of that the resultant Spaghetti which containing 5, 10 and 15\% guava seeds flour recorded good grade as cooking quality. In agreement to the obtained results were confirmed by those obtained by Haiat et al.,(2012) and Ahmed et al., (2011)

Table 6. Effect of replacing wheat flour with some processing wastes

\begin{tabular}{|c|c|c|c|c|c|c|}
\hline \multirow{3}{*}{ Raw material } & \multicolumn{6}{|c|}{ Mineral concentration $(\mathrm{mg} / 100 \mathrm{~g})$} \\
\hline & \multicolumn{4}{|c|}{ Macro elements } & \multicolumn{2}{|c|}{ Micro elements } \\
\hline & $\mathrm{K}$ & $\mathrm{Ca}$ & $\mathrm{Na}$ & $\mathrm{P}$ & $\mathrm{Fe}$ & $\mathrm{Zn}$ \\
\hline Wheat flour $72 \%$ exit & $115 \pm 2^{\mathrm{e}}$ & $19.6 \pm 0.3^{\mathrm{e}}$ & $4.01 \pm 0.07^{\mathrm{e}}$ & $43.70 \pm 0.8^{\mathrm{a}}$ & $1.20 \pm 0.2^{\mathrm{c}}$ & $0.79 \pm 0.05^{\mathrm{a}}$ \\
\hline $95 \% \mathrm{~W} . \mathrm{F}+5 \%$ DOA & $125 \pm 4^{\mathrm{d}}$ & $45.82 \pm 268^{\mathrm{d}}$ & $5.76 \pm 0.49^{\mathrm{d}}$ & $44.97 \pm 1.77^{\mathrm{a}}$ & $1.56 \pm 0.34^{\mathrm{bc}}$ & $0.82 \pm 0.07^{\mathrm{b}}$ \\
\hline $90 \% \mathrm{~W} . \mathrm{F}+10 \% \mathrm{DOA}$ & $135 \pm 4^{\mathrm{c}}$ & $77.4 \pm 2.2^{\mathrm{c}}$ & $7.56 \pm 0.34^{\mathrm{c}}$ & $46.26 \pm 1.76^{\mathrm{a}}$ & $2.08 \pm 0.93^{\mathrm{ab}}$ & $0.87 \pm 0.12^{\mathrm{b}}$ \\
\hline $85 \% \mathrm{~W} . \mathrm{F}+15 \%$ DOA & $145.3 \pm 1.2^{\mathrm{b}}$ & $105.76 \pm 0.74^{\mathrm{b}}$ & $9.34 \pm 0.16^{\mathrm{b}}$ & $47.53 \pm 0.47^{\mathrm{a}}$ & $2.51 \pm 0.24^{\mathrm{a}}$ & $0.89 \pm 0.07^{\mathrm{b}}$ \\
\hline $80 \% \mathrm{~W} . \mathrm{F}+20 \%$ DOA & $155.4 \pm 4.8^{\mathrm{a}}$ & $134.48 \pm 4.98^{\mathrm{a}}$ & $11.12 \pm 1.37^{\mathrm{a}}$ & $48.82 \pm 7.32^{\mathrm{a}}$ & $2.95 \pm 0.86^{\mathrm{a}}$ & $0.92 \pm 0.08^{\mathrm{b}}$ \\
\hline LSD & 6.3273 & 4.9796 & 1.2239 & 6.3374 & 1.0827 & 0.1383 \\
\hline \multicolumn{7}{|l|}{ Guava seeds } \\
\hline Wheat flour $72 \%$ exit & $115 \pm 2^{\mathrm{e}}$ & $19.6 \pm 0.3^{\mathrm{e}}$ & $4.01 \pm 0.07^{\mathrm{e}}$ & $43.70 \pm 0.8^{\mathrm{a}}$ & $1.20 \pm 0.2^{\mathrm{c}}$ & $0.79 \pm 0.05^{\mathrm{a}}$ \\
\hline $95 \%$ W.F+5\% G.S P & $126.45 \pm 5.7^{\mathrm{c}}$ & $38.22 \pm 5.72^{\mathrm{c}}$ & $19.64 \pm 1.6^{\mathrm{c}}$ & $52.04 \pm 3.76^{\mathrm{c}}$ & $2.7 \pm 0.5^{\mathrm{c}}$ & $0.75 \pm 0.03^{\mathrm{b}}$ \\
\hline $90 \%$ W.F+10\% G.S P & $137.9 \pm 1.4^{\mathrm{b}}$ & $56.82 \pm 5.83^{\mathrm{b}}$ & $35.26 \pm 0.46^{\mathrm{b}}$ & $62.58 \pm 1.33^{\mathrm{b}}$ & $4.14 \pm 0.36^{\mathrm{b}}$ & $0.71 \pm 0.02^{\mathrm{ab}}$ \\
\hline $85 \%$ W.F+15\% G.S P & $199.35 \pm 6.85^{\mathrm{a}}$ & $75.46 \pm 4.66^{\mathrm{a}}$ & $50.89 \pm 3.61^{\mathrm{a}}$ & $68.75 \pm 0.05^{\mathrm{a}}$ & $5.68 \pm 0.22^{\mathrm{a}}$ & $0.67 \pm 0.05^{\mathrm{c}}$ \\
\hline LSD & 8.6956 & 8.8527 & 3.8481 & 4.5704 & 0.6177 & 0.0692 \\
\hline \multicolumn{7}{|l|}{ Tomato peels } \\
\hline Wheat flour $72 \%$ exit & $115 \pm 2^{\mathrm{e}}$ & $19.6 \pm 0.3^{\mathrm{e}}$ & $4.01 \pm 0.07^{\mathrm{e}}$ & $43.70 \pm 0.8^{\mathrm{a}}$ & $1.20 \pm 0.2^{\mathrm{c}}$ & $0.79 \pm 0.05^{\mathrm{a}}$ \\
\hline $90 \% \mathrm{~W} . \mathrm{F}+10 \%$ TP P & $135.8 \pm 3.9^{\mathrm{d}}$ & $31.82 \pm 3.02^{\mathrm{d}}$ & $35.8 \pm 3.2^{\mathrm{d}}$ & $75.53 \pm 3.23^{\mathrm{d}}$ & $1.53 \pm 0.03^{\mathrm{c}}$ & $1.79 \pm 0.29^{\mathrm{d}}$ \\
\hline $80 \% W . F+20 \%$ TP P & $156.6 \pm 3.3^{\mathrm{c}}$ & $44.10 \pm 4.3^{\mathrm{c}}$ & $67.60 \pm 2.9^{c}$ & $107.36 \pm 3.24^{\mathrm{c}}$ & $1.86 \pm 0.42^{\mathrm{b}}$ & $2.79 \pm 0.21^{\mathrm{c}}$ \\
\hline $70 \% \mathrm{~W} . \mathrm{F}+30 \%$ TP P & $176.6 \pm 0.9^{b}$ & $56.36 \pm 1.54^{\mathrm{b}}$ & $99.4 \pm 0.8^{\mathrm{b}}$ & $139.19 \pm 2.06^{\mathrm{b}}$ & $2.19 \pm 0.06^{\mathrm{c}}$ & $3.79 \pm 0.11^{\mathrm{b}}$ \\
\hline $60 \% \mathrm{~W} . \mathrm{F}+40 \%$ TP P & $198.2 \pm 4.3^{\mathrm{a}}$ & $68.6 \pm 3.3^{\mathrm{a}}$ & $131.2 \pm 3.2^{\mathrm{a}}$ & $171.02 \pm 3.8^{\mathrm{a}}$ & $2.52 \pm 0.38^{\mathrm{a}}$ & $5.06 \pm 0.69^{\mathrm{a}}$ \\
\hline LSD & 5.7184 & 5.2072 & 4.42216 & 5.0568 & 0.4658 & 0.6396 \\
\hline
\end{tabular}

LSD =least significant difference.,WF 72\% ext.= wheat flour 72\% extraction , DOA= dry orange albedo, GS P guava seed power and TPP Tomato peel power. $\mathrm{K}=$ potassium, $\mathrm{Ca}=$ calcium, $\mathrm{Na}=$ Sodium, $\mathrm{P}=\mathrm{Phosphor}, \mathrm{Fe}=\mathrm{Iron}$ and $\mathrm{Zn}=\mathrm{zinc}$

Spaghetti replacement with tomato peel powder:

Table (7) Effect of adding different ratio from milled tomato peel powder on spaghetti cooking properties show cooking quality (Cooking loos $\%$, volume gain weight gain $\%$, and firmness \%) prepared from wheat flour $72 \%$ extraction substituted by different levels of some natural products ( $10,20,30$ and $40 \%$ in 10-12 min. The inclusion and substitution of wheat flour by tomato peel powder at different levels increased firmness values by increasing level of substitution where it reached 2.00,2.5,2.7 and $3.00 \mathrm{~kg} / \mathrm{cm}^{2}$ in the $72 \%$ ext. Compared WF72\% ext. control in spaghetti $1.45 \mathrm{~kg} / \mathrm{cm}^{2}$ 
In addition values for the cooking quality properties were increased by the inclusion and increasing level of substitution where weight gain reached $185,190,196$ and $205 \%$ respectively in the $72 \%$ ext.
Volume gain and weight gain were also increased to $193,197,209$ and $215 \%$ and $185,190,196$ and $205 \%$ in the $72 \%$ ext. group, respectively

Similarly, cooking loos values were increased: 5, 5.9, 7.2 and $9 \%$ in the $72 \%$ ext. group, successively. These results were agreement Marwa, (2013).

Table 7. Effect of Adding different ratios from milled) with some product wastes

\begin{tabular}{|c|c|c|c|c|c|}
\hline \multirow[t]{2}{*}{ Parameter } & \multirow{2}{*}{$\begin{array}{l}\text { cooking time } \\
\text { in } \min \end{array}$} & \multirow[t]{2}{*}{ Firmness $\left(\mathrm{kg} / \mathrm{cm}^{2}\right)$} & \multicolumn{3}{|c|}{ Cooking quality properties } \\
\hline & & & $\begin{array}{l}\text { Weight } \\
\text { gain (\%) }\end{array}$ & Volume gain $(\%)$ & Cooking $\operatorname{loss}(\%)$ \\
\hline WF $72 \%$ ext & $10-12 \min$ & 1.45 & 182 & 190 & 4.7 \\
\hline $95 \%$ W.F+5\% DOA & $10-12 \min$ & 2.13 & 190 & 198 & 7.07 \\
\hline $90 \% \mathrm{~W} . \mathrm{F}+10 \%$ DOA & $10-12 \min$ & 2.17 & 195 & 204 & 7.4 \\
\hline $85 \% \mathrm{~W} . \mathrm{F}+15 \%$ DOA & $10-12 \mathrm{~min}$ & 2.25 & 210 & 214 & 7.6 \\
\hline $80 \%$ W.F+20\% DOA & $10-12 \mathrm{~min}$ & 2.99 & 281 & 286 & 10.1 \\
\hline \multicolumn{6}{|l|}{ Guava seeds } \\
\hline WF $72 \%$ ext & $10-12 \min$ & 1.45 & 182 & 190 & 4.7 \\
\hline $95 \% \mathrm{~W} . \mathrm{F}+5 \%$ GS P & $10-12 \min$ & 2.5 & 185 & 195 & 6 \\
\hline $90 \% \mathrm{~W} . \mathrm{F}+10 \%$ GS P & $10-12 \mathrm{~min}$ & 2.7 & 190 & 198 & 7 \\
\hline $85 \%$ W.F+15\% GS P & $10-12 \mathrm{~min}$ & 3 & 195 & 200 & 9.5 \\
\hline \multicolumn{6}{|l|}{ Tomato peel } \\
\hline WF $72 \%$ ext & $10-12 \min$ & 1.45 & 182 & 190 & 4.7 \\
\hline $90 \% \mathrm{~W} . \mathrm{F}+10 \% \mathrm{TPP}$ & $10-12 \min$ & 2.00 & 185 & 193 & 5 \\
\hline $80 \%$ W.F+20\% TPP & $10-12 \min$ & 2.5 & 190 & 197 & 5.9 \\
\hline $70 \%$ W.F+30\% TPP & $10-12 \mathrm{~min}$ & 2.7 & 196 & 209 & 7.2 \\
\hline $60 \% \mathrm{~W} . \mathrm{F}+40 \%$ TPP & $10-12 \mathrm{~min}$ & 3.00 & 205 & 215 & 9.00 \\
\hline
\end{tabular}

\section{References}

A.A.C.C., American Association of Cereal Chemistry(2005). Approved Methods of American Association of Cereal Chemistry. 10 ${ }^{\text {th }}$ ed., St. Paul, Minneata

Abd-El-Hady, R. S. (2012).Utilization of defatted wheat germ flour as nutrient supplement of biscuits.J.Agric. Res. Kafer El-Sheikh Univ.,38(1):238-253.

Abd El-Moniem, G. M. and Yassen, A. A. (1993).High dietary fiber cookies from several sources of bran or husk.Egyption. J. Food Sci., 21 (2), 157-170.

Abd-Raboh, F.F(2007). Chemical studies on industrial tomato fruit wastes and its application in some bakery products. M. Sc. Thesis. Food Sci. and Technol. Dept.Fac of Agric. Tanta Univ. Egypt.

Abdeldaiem, M. H.; Hoda, G. M.and Nasr, E.H(2014) Antioxidant activity of extr from gamma irradiated guava (Psidiumguajava L.) seeds. Food Science and Quality Management Vol.26,13759.

Ahmed M.S. Hussein*, Mohie M. Kamil and Gamal F. Mohamed(2011) Physicochemical and Sensorial Quality of Semolina-Defatted Guava seeds Flour Composite Pasta Journal of American Science, 2011;7(6)

Alvarado, A.; Pacheco-Delahaye, E.andHevia,
P.(2001).Value of a tomato by-product as a source of dietary fiber in rat.Plant Food Hum.Nut. 56, 334-348.

Abd el slam, A.M. (2005).Production of noodles from different flowers of various extractions. M. Sc. Thesis, Food Tech. Dept., Fac. Of Agric, BenhaUniv.,Egypt.

Angelica Bianca P., Airannegale G., Charles Gilroy M., Dela Cruz D.,

Indiongco, Jose Lorenzo M. (2015). Dehydration of Pomelo (Citrus grandis) Albedo and Its Utilization as a Source of Dietary Fiber in Philippine Pork Sausag J. (Nat. Sci.) 49 : 606 614.

AOAC.(2005). Official of Analysis. (18 ${ }^{\text {th }}$ Ed.) Chapter 33, pp.10, 70 - 72, Chapter 45, pp101Association of Official Analytical Chemists.Washington, D.C., USA.

A.O.C.S. (1993): Official methods and recommended practices of the American Oil Chemists Society, $4^{\text {th }}$ ed. published by the American Oil Chemists Society, 1608, Broadmoor, Drive, Champaign, lllinois, 618263489.

Arafa, S.G. (2009).Utilization of tomato processing wastes as a source of protein and oil for supplementation of some bakery products. M. Sc. Thesis. Food Sc and Technol. Dept. Fac. of Agric., Kaferelshiekh Univ., Egypt. 
Ayman M.E.(2015) Nutritional composition, antinutritional factors, bioactive compounds and antioxidant activity of guava seeds(PsidiumMyrtaceae) as affected by roasting processes52(4): 2175- Published online 2013 Dec 27.

Babiker, W.A.M.:Sulieman, A.E.; E lhardallon, S.B. and khalifa, E.A.(2013). Phsicohemical properties of wheat breadupplemented with orange peel by-products. Inter. JNutr. Food Sci., 2(1):1:-4.

Baik, B.K. and Lee, M.R.2003.Effect of starch amylase content of wheat on textural properties of white salted noodles. Cereal Chem. 808 (3), $304-309$

Bedeir, S.H. (2004). Addition of gluten, pentosans, ascorbic acid and milk casein to wheat flour to produce a high quality bakery products. Ph.D. Thesis, Fac. of Agric., Moshtohor, Zagazig Univ., Benha Branch, Egypt.

Bilgicli, N. and Ibanoglu, S. (2007) Effect of wheat germ and wheat bran on the fermentation acivity, phytic acid content and color of tarhana, a wheat flour -yoghurt mixture.J. Food Eng.,(78): 681686.

Bilgicli,N.;Elgun, A.; Herken, N.;Turker, S.;Ertas, N. and Ibanoglu, (2006). Effect of wheat germ/ bran addition on the chemical, nutritional and sensory of tarhana, a fermented wheat flour yoghurt product. J. Food Eng.,(77): 680-686.

Dexter, J. E., R.R. and Morhan,B.C. (1983). Spaghetti stickiness : some factors influencing stickiness and relation ship to other cooking quality characteristics J. Food Sci., 48: 1545 1553.

Doweidar, M.M. (2001). Chemical and physical studies on some natural resources used in improving bakery products. Ph.D. Thesis, Fac. of Agric., Cairo Univ., Egypt

El Adly, N. and Asma, A. E.(2009). Utilization of meat sugar fiber industry ban bread. J. Agric. Sci. Mansoura Univr. 34 (7): 7749 - 7758.

El-Kassas, F.B. (2004). Utilization of vegeTable and fruit producessing wastes. Ph. D. Thesis, Food Tecnol. Dept., Fac. Agric., Suez Canal Univ., Egypt.

El-Safy, F.S., Salem, R. H.andAbd El-Ghany, M.E. (2012).Chemical and nutritional evaluation of different seed flour as novel sources of protein. World Journal of Dairy and Food Sciences.7(!): 59-65.

Fernndez-Ginés, J., Navarro, C., Sendra, E., Sayas, M., Ferndez-Ĺpez, J. and PérezIvarez, J. (2001).Colourimetric characterization of meat emulsion containing albedo.Vol II. pp. 162-163. In: Proceedings of 47th International Congress of Meat Science and Technology. Cracovia, Poland. 304 p.
Fernandez-Lopez, J.; Fernandez-Guines, J. M.; Aleson-Carbonell, L.; Sendra, E.; SayasBarbera, E. and Perez-Alvarez, J. A. (2004).Application of functional citrus byproducts to meat products, Trends Food Sci. Tech., 15:176.

Fontanari, G. G.; Souza,G. G.;Souza, G. R.;Batistuti, J. P.; Neves, V. A. and Fertonani,F.L.(2008). DSC studies on protein of guava seeds Psidiumguajava.Journal of Thermal Analysis and Calorimetry,93(2): 397bb-42.

Giovannucci E., Rimm E.B., Liu Y., Stampfer M.J. and Willett W.C. (2002).A prospective study of tomato byproducts, lyco-pene and prostate cancer risk. J. Natl. Cancer Inst. 94, 391398.

Kaur D, Wani AA, Oberoi DPS, Sogi DS.(2008). Effect of extraction conditions on lycopene extractions from tomato processing waste skin using response surface methodology.Food Chem. 108: 711-718.

Kerolles, S. Y. (1986). The pectic substances.Intercience Publishers, Inc., New Yrok.USA.

Knoblich, M., Anderson, B., \&Latshaw, D. (2005). Analyses of tomato peel and seed byproducts and their use as a source of carotenoids.J. Food Chem. 55: 455-470.

Manal, A.M. Hassan, A and Hend, M.(2014)Physico-Chemical properties and Sensory Evaluation of Toast Bread Fortified with Different Levels of White Grapefruit (Citrus paradise L.) Albedo Layer Flour.

Marquina, V.,LAraujo, Ruiz, A. Ruiz, A. Rodriguez-Malaver and P. Vit (2008).Composition and antioxidant capacity of the guava (psidiumguajava) fruit, pulp and jam. Archive LatinoamNutr., 58: 98-102.

Martinez-Valverde, I.;Periago, M. J.; provan, G.and Chesson. A.(2002).Phenolic compounds, lycopene and antioxidant activity in commercial varieties of tomato(Lycopersiumescuenlum). J. Sci Food Agric., 82:323-330g

Marwa, M. A. A.; (2013) Utilization of Food Processing Wastes in Forlification of some Biological Compounds this submitted in Fulfillment of the Requirements for the Degree of Master of Science in agriculturelqscience (food scence). Department of food Science Faculty of AgricutureKafer El Sheiakh University Egypt

Mervat, E. E. (2009). Effect orange albedo as new source dietary fiber on charactistics of beef burger.Faculty of specific Education Mansoura University- Egypt April8-9.

Norshazila, J. S.; Syed, Z. I.; Mustapha, S. K.; Aisyah, M. R. and Oikeh1 E. I., Oriakhi2 K. and Omoregie1* E. S(2013) Proximate Analysis and Phytochemical Screening of Citrus sinensis Fruit Wastes The Bioscientist: Vol. 1(2):164-170, September 
Packer, V.G., Selani, M.M., Gomes, F. G., Ruiz, J.N., Augusto, T.R., Contreras Castillo, C.J. \&Alencar S.M. (2010).Addition of beet and Guava agroindustrial residues in cooked and refrigerated chicken meat and its effect on lipid oxidation. International Conference in Food Innovation, 25- 29 October 2010, pp. 1-4.

Park, C., Kim, S. and Ahn, Y.J., 2003. Insecticidal activity of asarones identified in Acorusgramineus rhizome against three coleopteran stored product insects. J. Stored Prod. Res. 39, 333-342.

Samia El-Safy, F. Rabab,I.I Salem, H. andAbd El-Sabio, E.; M. Lozano; Montero de Espinosa; R.L.MendesCoeilho (2003).Lycopene and $\mathrm{b}$-carotene extraction from tomato processing waste using supercritical CO2. Ind. Eng. Chem. Res. 42:6641-6646.

Oikeh1 E. I., Oriakhi K. and Omoregie1 E. S(2013) Proximate Analysis and Phytochemical. Screening of Citrus Sinensis Fruit Wastes. TheBioscientist,Vol. 1(2):164-170, September.

Osfor.M.M.R.;Hegazy, A. ;Maha, A. ;Mohammad, A. E. ;Afify A. M. R.andAmr,
S.M.E (2013) Hypo-cholesterol emic and hypoglycemic effects of orange albedo powder (Citrus Uranium i.) on albino rats. International Journal of Nutrition and Food Sciences 2(2): 7076.

SAS Institute Inc. (1999).Statistical Analysis System. User's Guide: Statistics,SAS, Institute Inc Editors, Cary, NC.

Sogi, D.S.;Sidhu J.S.; ArraM.S.; GargS.K. and Bawa, A.S. (2002). Effect of tomato seed meal supplementation on the dough and bread characteristics of wheat (PBW) flour. Intr. J. Food Properties.5: 563-71.

Sonja M. Djilas; A.(2010). Utilization of tomato waste as source of polyphenolic antioxidants biblid : 1450-7188) 40.

Tao N.G, Liu Y.J, Zang J.H, Zeng H.Y, Tang Y.F. (2009). Chemical composition of essential oil from the peel of Satsuma Mandarin. African J Biotech 7: 1261-1264.

Thuaytong W, Anprung $P$ (2011) Bioactive compounds and prebiotic activity in Thailandgrown red and white guava fruit (Psidiumguajava L). Food SciTechnolInt 17: 205-212. 